\title{
First edition and translation of an unpublished poem (1566) from Johanna Otho to Camille de Morel*
}

\author{
KAITLIN KARMEN
}

This paper presents the first full edition and translation of an unpublished (1566) poem written by Johanna Otho and sent to Camille de Morel. Both young women, linked by their mutual acquaintance Karel Utenhove, were internationally recognized for their learning. Otho's poem is a significant contribution to the corpus of women's Latin poetry. This paper also offers a brief introduction to the poem's historical context and suggests contemporary political resonances for Otho's poem. Her poem contains allusions to the conflict between courtly life and religion, which reference the ongoing conflict between Protestants and Catholics in Europe and specifically France.

\section{Introduction}

Johanna Otho was born in Ghent in ca. 1545/50. She and her family moved to Duisburg in the $1560 \mathrm{~s}$, probably to flee religious persecution after the family's conversion to Protestantism. Johanna's father Johann Otho was a noted humanist, grammarian, translator, cosmographer, and teacher, whose most famous pupil was Karel Utenhove (1536-1600). ${ }^{2}$ Utenhove himself grew to become an internationally recognized polyglot, poet, scholar, and diplomat. His family had a tradition of educating their daughters and women, such as Anna Utenhovia, Anna van Pallandt, and Johanna van Pallandt. ${ }^{3}$ This connection with Utenhove thus linked Johanna Otho to other learned women, the world of Protestant humanism, and an international literary network. ${ }^{4}$ Johanna was, for

* I would like to thank Ian Fielding, George Hoffmann, Demmy Verbeke, the editors, and the anonymous peer reviewers for their invaluable feedback.

2 J. Stevenson, "Johanna Otho (Othonia) and Women's Latin Poetry in Reformed Europe", in L.J. Churchill, P.R. Brown, J.E. Jeffrey (ed.), Women Writing Latin. Early Modern Women Writing Latin (New York, NY, 2002), 189-215, at 191.

3 J. Stevenson, Women Latin Poets. Language, Gender, and Authority from Antiquity to the Eighteenth Century (Oxford, 2005), 244-245. See also W. Janssen, Charles Utenhove. Sa vie et son oeuvre (1536-1600) (Maastricht, 1939).

${ }^{4}$ Stevenson 2002 (as in n. 1), 194. 
example, greatly admired by the prominent German literary humanist, Paul Melissus, with whom Utenhove maintained a friendship. ${ }^{5}$

In 1557 Utenhove moved from Otho's school in Ghent to Paris, where he became involved in prominent scholarly and literary circles and corresponded with an array of European intellectual figures. ${ }^{6}$ His connections included figures such as Jean Dorat, Joachim du Bellay, Pierre de Ronsard, and others who gathered at the home of the Morel family on the rue Pavée, one of Paris' first literary salons. ${ }^{7}$

In Paris in 1557, Karel Utenhove was employed by Jean de Morel and Antoinette de Loynes ${ }^{8}$ to tutor their children, Isaac (b. 1542-1546), Camille de Morel (1547-after 1611), Lucrèce (b. 1548/1549), and Diane (b. 1550). ${ }^{9}$ It was later rumored that Utenhove had attempted to convert his Catholic pupils to Protestantism. ${ }^{10}$ The Morel family were associated

${ }^{5}$ L. Foster, "Charles Utenhove and Germany", Daphnis 6.4 (1977), 81-100, at 87-89.

${ }^{6}$ Stevenson 2005 (as in n. 2), 238-240.

7 The Morel family's literary salon began in the 1540s. Many attendees were neoLatin poets. The peak of the salon's activities was in the $1550 \mathrm{~s}$, when the Pléiade poets frequented the home. This intellectual circle was humanist. (Stevenson 2002 [as in n. 1], 193; P. Ford, "An Early French Renaissance Salon. The Morel Household", Renaissance and Reformation / Renaissance et Réforme 28.1 [2004], 9-20, at 10; J.D. Campbell, "Crossing International Borders. Tutors and the Transmission of Young Women's Writing", in J.D. Campbell, A.R. Larsen [ed.], Early Modern Women and Transnational Communities of Letters [Farnham, 2009], 213-228, at 221). The Morel home has even been called "le premier salon littéraire de Paris." See S.F. Will, "Camille de Morel. A Prodigy of the Renaissance", Publications of the Modern Language Association 52.1 (1936), 83-119, at 83-85.

8 Jean de Morel and Antoinette de Loynes were themselves impressive intellectual figures in their day. Jean de Morel (b. 1510) had significant political and literary connections. Morel traveled extensively in Germany and Switzerland where he met important contemporary figures. He even became an intimate friend of Erasmus up until Erasmus' death. His later career led him to the French court, where he was selected by Catherine de Médicis to be the preceptor of Henri II's biological son, Henri d'Angoulême. From 1550 to 1560 he was a friend and adviser to the illustrious Pléiade poets. Antoinette (b. 1505) received an early education in classical languages and literature. After her marriage to Jean de Morel, she befriended those who frequented the Morel's home, including Ronsard, Du Bellay, Michel de L'Hospital, Salmon Macrin, Nicolas Bourbon, Charles and Scévole de Saint-Marthe, Nicolas Denisot, and Jean Dorat (Will 1936 [as in n. 6], 85). For the importance of literary families in Renaissance France, see N. Kenny, Born to Write. Literary Families and Social Hierarchies in Early Modern France (Oxford, 2020).

${ }^{9}$ Ford 2004 (as in n. 6), 10.

10 Stevenson 2005 (as in n. 2), 189. Stevenson, citing S.F. Will, notes that Jean de Morel had been a friend of Erasmus. He remained a Catholic humanist and did not convert to reform doctrine. Other contemporaries, such as George Buchanan, used their teaching positions to introduce students to Protestant values (G. Hoffmann, "Montaigne's Education", in P. Desan [ed.], The Oxford Handbook of Montaigne [Oxford, 2016], 40-57, at 46). 
with the French court as a family of minor nobility, and their reputation was heightened by Jean's position as a courtier. ${ }^{11}$ Utenhove remained with the Morels from 1557 to 1561, after which he departed for Scotland and England, although he maintained contact with the Morels. ${ }^{12}$ An undated letter written by Utenhove to Jean de Morel may suggest a reason for Utenhove's departure. Isaac de Morel had left Paris around 10 October 1561; he seems to have traveled to Scotland which had recently accepted Calvinism after breaking from the Catholic church. He disappears from the historical record, and his activities are only known from references in others' correspondences. ${ }^{13}$ Utenhove writes in his letter,

Concerning what you seemed to hint to me today quite openly, that you have been thinking about searching out another tutor for your children, more learned and better than myself, and more suitable for carrying out this task, because I am a doer of evil and corrupter of the youth like Socrates, that you make it known to me quickly, so that, since, trusting in the goodness of God alone, I do not despair, and since my situation has not yet yielded to extreme despair, I may either take care of myself, or look out for another situation, or at least a not too disagreeable place to live. ${ }^{14}$

11 Stevenson 2002 (as in n. 1), 193.

12 Campbell 2009 (as in n. 6), 221, 223.

13 P. Ford, "Carolus Utenhovius (1536-1600). A Tale of Two Cities", in J. de Landtsheer, H.J.M. Nellen (ed.), Between Scylla and Charybdis. Learned Letter Writers Navigating the Reefs of Religious and Political Controversy in Early Modern Europe (Leiden, 2010), 149-160, at 151-152.

14 Translated in Ford 2010 (as in n. 12), 150-151. The original text, as printed by Ford with minor modification, reads: quod hodie mihi non obscure innuere uisus es, de alio tuorum $\pi \alpha \iota \delta \alpha \gamma \omega \gamma \tilde{\omega}$ et doctiore, et meliore, et ad hanc functionem magis idoneo inuesti-

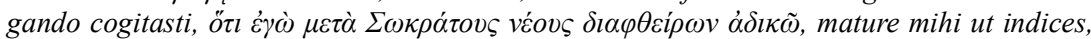
ut et ego mihi, quod solius Dei benignitate fretus non despero, reb[us] nostris nondum in extremam desperationem adductis, uel consulere, uel de conditione alia, uel loco habitationis saltem non incommodo prospicere, possim.

Humanistica Lovaniensia 70.2 (2021), 209-227 
It is thus possible that Isaac left Paris for Scotland for the religious freedom to practice Protestantism and that Utenhove was held responsible for Isaac's departure. In later correspondence with Morel, Utenhove mentions Isaac, once stating that he had dreamed that Isaac would soon return home to the Morels. Isaac, however, never returned. ${ }^{15}$

Utenhove also had significant influence upon Isaac's sister, Camille. He was instrumental in establishing throughout Europe Camille de Morel's reputation as a prodigy. ${ }^{16} \mathrm{He}$ successfully promoted her and established connections between her and other important figures in his literary circle. Some, like Michel de L'Hospital, Jean Dorat, and Joachim du Bellay took active interest in Camille. ${ }^{17}$ In a poem of 1558 , du Bellay goes so far as to write of the eleven-year-old Camille: "Camille plays so well with Latin measures, that you would think Camille was brought up in Latium. Camille speaks Greek so well that you would swear that Athens [itself] is less Attic" (sic ludit Latiis modis Camilla, / Camillam ut Latii putes alumnam. / Sic Graece loquitur Camilla, iures / ut ipsas minus Atticas Athenas). He also compliments her Hebrew and French. ${ }^{18}$ Such dedicated commitment as Utenhove's to the promotion of Camille's career, and specifically her Latin poetry, was one of few avenues by which women could garner reputation. He acted as a publicist for her, and, in part, his own reputation as a teacher depended upon her success. The high point of Camille's literary career was in her early life when her parents' literary salon flourished and Utenhove continued to promote her work internationally. ${ }^{19}$

Utenhove, reconnecting with his old teacher in Ghent after his stay in Scotland and England, brought the young women Latinists Johanna

${ }^{15}$ Ford 2010 (as in n. 12), 156.

${ }^{16}$ Campbell 2009 (as in n. 6), 225.

17 Will 1936 (as in n. 6), 99.

18 Cited and translated in P. Ford, "Camille de Morel. Female Erudition in the French Renaissance", in G. Ferguson, C. Hampton (ed.), (Re)Inventing the Past. Essays on French Early Modern Culture, Literature and Thought in Honour of Ann Moss (Durham, 2003), 245-259, at 250-251.

19 Campbell 2009 (as in n. 6), 227-228. 
Otho and Camille de Morel into contact. ${ }^{20}$ In 1566 Otho wrote a letter to Morel at his suggestion. ${ }^{21}$ In it Johanna requested that the Morel family assist her brother, who was also in Paris. ${ }^{22}$ However, no lasting friendship seems to have developed between the two women. ${ }^{23}$ The letter, like the accompanying poem, addresses Camille's reputation of being learned in Greek and Latin, while also including comments on the constraints that domestic responsibilities placed on women's learning. In the letter, Johanna writes that, "For me, indeed, if I am to admit the truth, no pleasure can come my way which is so great that, through concern for it, I would be able to give second place to Latin and Greek letters. It is by them that I measure not only my enjoyment, but indeed my happiness. If only I were able to spurn domestic cares (something which, in us, most people regard as a crime) for their sake!'24

${ }^{20}$ Utenhove was known to have had links with at least eight other women Latin poets: Anna and Johanna von Pallandt, Anna Utenhovia, Margaretha Bock van Gutmansdorf, Petronia Lansenberg, Elizabeth I, Mildred Cecil, Rosina Schede, and Maria Thou (Stevenson 2005 [as in n. 2], 240).

${ }^{21}$ A full translation of the letter is given in Stevenson 2005 (as in n. 2), 239. The Latin text, as printed in R.L. Hawkins, 'A letter from one maiden of the Renaissance to another', in Modern Language Notes 22.8 (1907), 243-5, is:

S. P. Cum ad nos ex Anglia venisset Dominus Carolus Utenhovius, quem pater meus inter eos quos olim in literis erudivit unice amplectitur, tuum mihi carmen dedit, quo lecto, verbis consequi nequeam quam fuerim gavisa. Nam in his terris nullam audio virginem in literis humanioribus magnopere versatam; quare aequum est quod tuae gratuler felicitati, ingenio et educationi, quod virgineis moribus in tanta generis tui claritate literas latinas et graecas coniungere non erubescas, novemque Musarum et Phoebi sacra tuis studiis non indigna censeas. Mihi sane, ut verum fatear, nulla potest voluptas obvenire tanta, cuius respectu literas latinas et graecas queam posthabere. Quibus non tantum voluptatem, sed veram felicitatem metior. Utinam domesticas curas (quod plerique in nobis nefas ducunt) prae his contemnere possem, facile paterer me totam solis Musis dedicari. Ignosce, clarissima virgo, meae audaciae, quod hac parum culta epistola tuas aures eruditissimas onerare sum ausa. Rogavit Dominus Carolus Utenhovius patrem meum ut etiam soluta oratione ad te aliquid literarum darem, meque in tuam notitiam propter literarum commercia insinuarem; quamobrem si quid hic peccati est, id totum Domino Carolo Utenhovio tua humanitas imputabit. Vale, lectissima Domina Camilla, et me in tuarum ancillarum catalogo ascribi patiare. Est mihi Lutetiae frater germanus. Utinam ille per te in familia isthic pia alibi commendatus potius quam oikóoltos viveret (sic). Iterum vale. Dunburgi. Pridie calendas octobris. Johanna Othonis, Johannis Othonis filia.

${ }^{22}$ Stevenson 2005 (as in n. 2), 189-90.

${ }^{23}$ Campbell 2009 (as in n. 6), 226.

${ }^{24}$ Stevenson 2005 (as in n. 2), 239. 
This letter has a long history of scholarly attention-beginning in 1907 with Hawkins's publication of the Latin text and continuing into the twenty-first century with Jane Stevenson's translations in Women Writing Latin and Women Latin Poets. The poem, on the other hand, has received little attention, often mentioned but left unpublished and untranslated. ${ }^{25}$ It does not appear in the early seventeenth-century publications of Johanna's works, Carminum diversorum libri duo (Strasbourg: A. Bertramnus) in 1616 and Poemata sive lusus extemporanei (Antwerp: Gulielmus à Tongris) in $1617^{26}$, perhaps because it was part of a private correspondence, not intended for wider publication.

The complete text of the poem is found in ms. Clm 10383, which has been made available in digital format by the Bayerische Staatsbibliothek (BSB). ${ }^{27}$ Ms. Clm 10383 is substantial. The BSB lists James Ussher (1581-1656) as the 1639 Verfasser of the 558-page manuscript. Ussher (1581-1656) was an Anglo-Irish primate in the Anglican church. He was a scholar with great knowledge of Arabic and Hebrew, and he wrote about Christianity in Asia Minor. He opposed Roman Catholicism. ${ }^{28}$ The first letter in the manuscript, addressed to Reformed theologian Friederich Spanheim, was written by the compiler, James Ussher, on June 20, 1629 in Dublin (f. 2r.). ${ }^{29}$ This considerable manuscript, as indicated on the binding and on dividing section pages, includes, among others: letters of Michel de L'Hospital, Claude Saumaise, Scévole de Sainte-Marthe, Jean de Morel, and Karl Utenhove (f. 91r); an elogium by Petrus Paschali (f. 215r); letters of Antoinette de Loynes, Delphina Tornatoria, and Camillus Peregrinus; poems and letters of Camille de

25 The first six lines of the Latin text along with a translation are given in Ford 2010 (as in n. 12), 157.

26 Stevenson 2002 (as in n. 1), 193-194. Stevenson characterizes the first book as an attempt to secure patronage because of its address to Protestant European monarchs and prominent figures in Strasbourg and Antwerp. The second part of this first publication covers topics like virginity, widowhood, and education and seems to "represent a relatively private meditation on her own status as a learned woman who was not a learned virgin."

27 München, Bayerische Staatsbibliothek, ms. Clm 10383. https://opacplus.bsbmuenchen.de/title/BV037453160.

28 Britannica Academic, s.v. "James Ussher". For more information on Ussher's beliefs, see I.W. Campbell, "Calvinist Absolutism. Archbishop James Ussher and Royal Power", Journal of British Studies 53.3 (2014), 588-610.

${ }^{29}$ C. Strohm, "Spanheim", in H.D. Betz, D.S. Browning, B. Janowski, E. Jüngel (ed.), Religion Past and Present (Leiden, Boston, 2012), 187. Friedrich Spanheim the Elder lived from 1600-1649. 
Morel, Petronia Lansenberg, ${ }^{30}$ and other women (f. 232r); Isaac Casaubon's letters to Saumaise and Thomas van Erpe's letters to Casaubon (f. 410r); some writings of Saumaise and Casaubon (f. 455r); and, the testament of Joseph Scaliger (f 554r). All the authors were significant religious or intellectual figures, many of whom were Protestant or sympathized with Protestants. ${ }^{31}$ The French scholars Joseph Justus Scaliger (1540-1609) and Isaac Casaubon (1559-1614) were both Huguenots who died in exile. Claude Saumaise (1588-1653) was an influential French classical scholar and polyglot; he was also a Calvinist. Thomas van Erpe (1584-1623) was a Dutch oriental scholar and publisher and pupil of Scaliger. ${ }^{32}$ While ms. Clm 10383 contains many different figures, each person was renowned for their learning and contemporary influence.

As noted by Philip Ford, a sizable portion of ms. Clm 10383 centers on the Morel family, both items addressed to and written by them. Others are from and by people in the Morel's circle, particularly those who frequented their literary salon. ${ }^{33}$ The section beginning on f. $232 \mathrm{r}$. is titled Antoniae De Loynae et Delphinae Tornatoriae Epistolae. Peregrini Camilli duae epistulae. Camillae Morellae, Petroniae Laurenbergiae, et aliarum feminarum versus vel epistolae. The majority of texts in this section are either authored by, translated by, or dedicated to Camille de Morel. Others relate to others in the Morel family and Utenhove, such as a poem from Utenhove's Xenia dedicated to Queen Elizabeth I of England and translated into Latin from the original Hebrew by Camille (f. 258r), a poem dedicated to Diane de Morel (f. 264r), and a French letter from Lucrèce de Morel (f. 265r.).

Johanna Otho's poem is found in this particular section of the manuscript. A consistent theme throughout the poem is the superiority of

30 Like Johanna Otho, Petronia Lansenberg was from Ghent. She learned Greek and Latin and maintained a friendship with Karel Utenhove, even appearing in his Xenia. She lived in London where she was a member of the Dutch Calvinist Church (Stevenson 2005 [as in n. 2], 245).

31 A notable exception to this is the testament (f. 566r) of the Polish Catholic archbishop of Lviv, Jan Dymitr Solikowski (1583-1603), who was devoted to the re-Catholicization of Poland (B. Stasiewski, and Z. Zielinski, "Poland, The Catholic Church in", in New Catholic Encyclopedia, vol. 11 [Detroit, MI, 2003], 438-455).

32 P. Hoftijzer, "Erpenius, Thomas", in M.F. Suarez, S.J., H.R. Woudhuysen (ed.), The Oxford Companion to the Book (Oxford, 2010), 703-704.

33 P. Ford, The Judgment of Palaemon. The Contest between Neo-Latin and Vernacular Poetry in Renaissance France (Leiden, 2013), 128-130, 222-223. Throughout this book, Ford discusses numerous correspondences and poems of Morel and his associates. 
religious life to the luxuries of the royal court. Stevenson suggests that the poem uses the humanist trope of comparing the lasting joys of religion and scholarship with the short-term delights of the royal court, which could indicate Johanna's ignorance that Camille's father Jean de Morel was a courtier associated with Henri II and Catherine de Médicis. $^{34}$ However, the poem also suggests that Johanna may have suspected that Camille herself would have been considering a position at the royal court. Johanna wrote: $i$ nunc docta Camilla, i nunc et pronuba fias / sponsae quae socias format amatque malas ("Go now, learned Camilla, go now and may you be the attendant of a bride-to-be, who makes her companions bad and loves them," 57-58). The strong, disapproving language of the poem, as suggested by the previous quote, allows for at least two interpretations. Johanna almost certainly knew, through Utenhove, of the Morel family's social standing and proximity to the French court. This disparaging comment about the sponsa could indicate a warning from Johanna to Camille. Alternatively, the tone may, as in Stevenson's characterization, suggest that the poem is merely a routine on a common topic. ${ }^{35}$

Poets criticizing the French court increased in number after 1560 during the Religious Wars. In this period, criticism of individual courtiers, rather than the general class, became more common. ${ }^{36}$ These political poems often juxtaposed the life of the courtier and rustic living, although they were more often written in the vernacular than in Latin, and by male authors than female. ${ }^{37}$ (Exceptions are the poems of Madeleine Neveu [ca. 1520-1587] and Catherine Fradonnet [ca. 1542-1587], also known as the Dames des Roches, whose writings reflect the contemporary destructiveness of Wars of Religion. Their poetry sets them apart from earlier women poets, whose writings were apolitical. ${ }^{38}$ )

While Johanna Otho's poem fits into the predominantly male paradigm of politically engaged poetry, one must remember the context of

34 Stevenson 2005 (as in n. 2), 240.

35 "The long poem which she [Otho] sent with the letter was unfortunate in its choice of subject: it expatiates at some length on the standard humanist trope of comparing the solid joys and lasting pleasures of religion and the scholarship with the ephemeral delights of royal courts" (Stevenson 2005 [as in n. 2], 240).

36 P.M. Smith, The Anti-Courtier Trend in Sixteenth Century French Literature (Genève, 1966), 160.

37 Smith 1966 (as in n. 35), 152-218, 224.

38 C.M. Bauschatz, "To Choose Ink and Pen. French Renaissance Women's Writing", in S. Stephens (ed.), A History of Women's Writing in France (Cambridge, 2000), 54. 
the poem: that it was included in a letter to Camille, where she asked a favor on behalf of her brother. It presents a pointed, and contemporarily situated, contrast between the Catholic court and the Protestant home, a contrast that would directly pertain to Camille's life. This argument is strengthened by the possible allusion to the Edict of Amboise at lines 41-46, where the home is established as the place of "true religion," language which reflects the Edict's statement that every person can practice religion in their home without investigation or restriction. ${ }^{39}$ Furthermore, the poem's private transmission suggests a more personal appeal. Potential elements of satire would not, in any case, preclude the possibility of a direct connection to Camille's personal life. And, because of the Morel family's known connection to the court, it seems unlikely that Otho's poem would have been written in ignorance of Camille's potential appointment to the court. Otho's poem is thus likely pointed in its choice of subject matter, rather than a stock piece of poetry, especially considering its specific invocation of its addressee. As a Protestant who fled persecution, Johanna's aggressive tone cautions Camille against joining the Catholic French court.

If Johanna's knowledge of Camille's family is accepted, the poem merits further analysis, particularly in its suggestions about Camille's life.

The sponsa of the poem - with whom Camille could have considered a position-could refer to numerous women. Because of the Morel family's pre-existing connections to the French court, a position there is most probable. In the French court then, this sponsa would have been either a daughter of Catherine de Médicis and Henri II of France or a woman born to another royal family who was marrying a son of Catherine and Henri for political reasons. Because this woman is a sponsa, bride-to-be, she would be young in the 1560s. Two likely possibilities for this sponsa are Elizabeth of Austria and Marguerite de Valois.

39 The 1563 Edict of Amboise states: "chacun pourra vivre et demeurer par tout en sa maison librement, sans être recherché ni molesté, forcé ni contraint pour le fait de sa conscience" (A. Stegmann, Édits des guerres de religion, [Paris, 1979], 34). 
Elizabeth of Austria (Archduchess Elizabeth of Habsburg) was born in Vienna in 1554 to the uncrowned king and queen of Bohemia, Maximilian and María-Maximilian would, however, later become Holy Roman Emperor. ${ }^{40}$ Elizabeth became the Queen of France in 1571 when she married Charles IX (r. 1560-1574), son of Catherine de Médicis and Henri II. ${ }^{41}$ An agreement of marriage between Elizabeth and Charles was not made until 1569. However, from the late $1550 \mathrm{~s}$ through the 1560s, Catherine de Médicis and Elizabeth's parents were in contact and repeatedly discussed a potential marriage. The topic was broached in the summer of 1560 when Bernardin Bochetel, an ambassador sent by the French crown, visited the Habsburg residence. It was discussed seriously again in 1562, 1566, and, for a final time, in 1568 . Elizabeth's father Maximilian had himself long considered the idea of a marriage between one of his daughters and a French royal. The death of King Henri I and the failing health of his heir Francis made more appealing the option of Elizabeth marrying the young Charles - this would position Elizabeth as future queen of France. But Charles was not the only potential husband for Elizabeth. Others such as Sebastian, son of Elizabeth's aunt Dowager Princess Juana of Portugal were potential spouses. Elizabeth was educated by religious men, including the bishop Caspar von Logau and Jesuits. Her education was likely heavily influenced by Spanish culture and language. ${ }^{42}$ It is possible that Camille de Morel might have been considered for employment by the Habsburgs as tutor or attendant to the teenage Elizabeth. Yet, the uncertainty of Elizabeth's marriage at the time of Johanna Otho's letter in 1566 may make this less likely.

40 J.F. Patrouch, Queen's Apprentice. Archduchess Elizabeth, Empress Maria, the Habsburgs, and the Holy Roman Empire, 1554-1569 (Leiden, 2010), 12.

${ }_{11}$ R.J. Knecht, The French Renaissance Court, 1483-1589 (New Haven, CT, 2008), xxiii, 432-433.

${ }^{42}$ Patrouch 2010 (as in n. 39), 90, 129-137, 201, 209, 268, 314-315, 368, 394, 399. 
Marguerite de Valois ${ }^{43}$ (also Margaret of Valois or Margot) was born to Henri II and Catherine de Médicis on 14 May 1553. ${ }^{44}$ Catherine desired a politically expedient marriage for Marguerite. Catherine proposed a marriage between Marguerite and Philip II's son Don Carlos, but this was turned down. ${ }^{45}$ Marguerite was eventually engaged to Henry of Bourbon, the future king of Navarre. ${ }^{46}$ Henri King of Navarre would later become Henri IV, King of France (1589-1610). ${ }^{47}$ The marriage of Marguerite and Henri on 18 August 1572 was intended to bring peace between the Protestants and Catholics, since Henri was a leading figure of the Huguenot Protestant party, with whom the Catholic royal family had been in conflict for a while. Thus in the $1560 \mathrm{~s}$, Marguerite would have been a young sponsa, a young woman for whom a politically expedient marriage was being arranged. Little is known about Marguerite's childhood. She did spend a lot of time at the Château of Vincennes with her brothers Henri d'Anjou (Henri III) and François d'Alençon. ${ }^{48}$ Because of Marguerite's age in the 1560 s, it is possible that she could have been the sponsa Otho mentions, especially given her proximity to Camille de Morel. And Camille would have had a more direct connection to the French court because of her father's previous employment as preceptor to Catherine de Médicis's son Henri d'Angoulême, who remained with Jean de Morel until 1567. Moreover, Camille likely met Marguerite and her siblings, since Jean Dorat, Henri d'Angoulême's prior tutor, conducted their education in the Morel household in 1554.49 Although no definitive identification can be made, this sponsa is doubtless a powerful young woman with a connection (or potential future connection) to the French court.

43 Marguerite wrote memoirs of her life. See Memoirs of Margaret de Valois, Queen of Navarre (London, 1895). See also C. Magnien and É. Viennot (ed.), De Marguerite de Valois à la reine Margot. Autrice, mécène, inspiratrice (Rennes, 2019).

44 C.M. Bauschatz, "Marguerite de Valois (1553-1516)", in D. Robin, A. Larsen, C. Levin (ed.), Encyclopedia of Women in the Renaissance. Italy, France, and England (Santa Barbara, CA, 2007), 231-233.

45 R.J. Knecht, Catherine de' Medici (New York, NY, 2014), 76, 108.

46 Bauschatz 2007 (as in n. 43), 231.

47 Knecht 2008 (as in n. 40), 432-433.

48 H.N. Williams, Queen Margot. Wife of Henry of Navarre (New York, NY, 1911), 3, 11 .

49 Stevenson 2005 (as in n. 2), 182-183. 
While Johanna's knowledge of Camille cannot be determined definitively, her inclusion of this detail may provide significant information about the life of Camille de Morel, which becomes more obscure after the early 1560s. Camille's association with the French court would have had political and religious significance during this contentious period in French history, the years of the Wars of Religion, a series of conflicts between Catholics and Huguenots from 1562 until 1598. Provisional compromises were reached between the government and the Huguenots in 1563,1568 , and 1570 , but these were unsuccessful in alleviating the political tensions. At the time of Johanna's writing the letter in 1566, six years had passed since the Conspiracy of Amboise, where the Huguenots had attempted but failed to kidnap Francis II (r. 1559-1560), eldest son of Henri II and Catherine de Médicis. The Edict of Amboise was given in 1563, ending the first civil war and allowing Protestants to practice their faith in their homes without investigation. ${ }^{50}$ Johanna's advice to be wary of the court was prescient as this peace did not last. In 1567, the second civil war commenced, ended by a brief peace in 1568 . In September 1568, Charles IX signed an edict prohibiting all nonCatholic religions. ${ }^{51}$ Johanna Otho's correspondence with Camille, warning her of the dangers of the court, thus takes on new significance, as a message from a Protestant refugee to her Catholic contemporary. Because of Johanna's exhortation, however, it could be argued that she was imagining Camille, in her role as attendant to a sponsa, as a positive influence for religious tolerance in the French court because of her humanist sympathies.

After 1566, Camille retained her reputation as a learned woman poet. While many specifics of her life remain obscure, she did publish her Tumulus in 1583. It was dedicated to her father who had died in 1581, though there are also poems for her mother and two deceased sisters. Jean Dorat also contributed poems to the collection. Camille included poems critical of those who did not contribute to the Tumulus, including Ronsard, Scévole de Sainte-Marthe, and Karel Utenhove. ${ }^{52}$ Camille maintained contact with Utenhove until his death in 1598. Stevenson also notes that Camille continued to be mentioned by French men into

50 Britannica Academic, s.v. "Catherine de Médicis"; s.v. "Huguenot"; s.v. "Wars of Religion." For a detailed account of the Wars of Religion, see N. Le Roux, Les guerres de religion (1559-1629) (Paris, 2009).

${ }^{51}$ Knecht 2014 (as in n. 44), 40.

52 Ford 2003 (as in n. 17), 254-255. 
the early seventeenth century. It is believed that Camille died as a protestant. ${ }^{53}$ At some point after 1566, Johanna Otho married Willem Mayart, but he died before 1616. Mayart was an advocate to the Council of Flanders. ${ }^{54}$ Her literary career continued, as evidenced by her two publications in 1616 and 1617, Carminum diversorum libri duo and Poemata sive lusus extemporanei (Antwerp: Gulielmus à Tongris).

Despite the relative early fame that Camille de Morel enjoyed over Johanna Otho, eventually Otho seems to have had a more prolific publishing career. Johanna Otho's poem, published in its entirety for the first time here, is a substantial contribution to the corpus of women's Latin poetry - totaling eighty-four lines of elegiac couplets-and a crucial text to any study of Renaissance women and women's Latin poetry more broadly.

${ }^{53}$ Ford 2013 (as in n. 32), 130.

${ }^{54}$ Stevenson 2005 (as in n. 2), 241. 


\section{Text and translation ${ }^{55}$}

Ad Camillam Morellam genere, pietate et literis Latinis et Graecis nobilem virginem. Jana Jani Othonis filia.

Ore mihi vultuque licet non nota Camilla, attamen ex docto carmine nota mihi es,

quod mihi Pieridum vates Phoebique sacerdos Carolus Utenhovus sympatriota dedit;

ille mei columen, decus, et pia cura parentis, haec mittenda suae carmina duxit herae.

Aulae magnificum nomen seu gloria vanae est levis, est mendax, nil pietatis habet.

Ne fallare cave, nihil est pietatis in aula, dum quid in hac magni vulgus inane videt.

Qui venit ex aula quemque excipit aula frequenter monstrari digito ${ }^{56}$ gaudet amatque coli.

Mandens frena ferox sonipes quem portat, alit rex; semideo populus credit habetque parem.

Est prope divinum dici nunc aulicus, aula plaerisque est quod sunt atria celsa Iovi, cum nihil infidum magis aut quid inanius illa. Ergo quid aula sonet quaerere cura mihi est. Caula sonat Graiis, quod nunc sonat aula Latinis, porcorum atque ovium tecta domus et harae.

Olim ollas aulas veteres dixere Latini, regia nunc regum dicitur aula domus, quae tantum foeda est hominum sentina malorum, queis ${ }^{57}$ penes improbitas tecta decore latet.

In caula est satius multos quam vivere in aula, caula tenet iustos, impia at aula malos; est rudis in caula caprarum oviumque magister, lanigerum innocuum, setigerumque pecus.

55 München, Bayerische Staatsbibliothek, ms. Clm 10383, ff. 250r-251r. In this edition, I have made little editorial intervention, except where noted. All but proper nouns or adjectives are lowercase. I have retained the manuscript spellings, except in the case of $i j$, which I have rendered as $i i$ in this text. Ligatured diphthongs have not been reproduced (e.g. $\alpha$ has been written as $a e$ ). I have distinguished between $u$ and $v$. Modern punctuation has been added.

${ }^{56}$ A phrase used by, e.g., Horace at Sat. 2.8.26 and Carm. 4.3.22.

${ }^{57}$ Queis is an alternative form of quibus. One would expect quos here. 
To Camilla Morella [Camille de Morel], a virgin renowned by birth, her piety, and her Latin and Greek letters. From Johanna, daughter of Johann Otho.

Although Camilla, you are not known to me by face or looks, nevertheless, you are known to me through your learned poem,

which the prophet of the Muses and the priest of Apollo, my compatriot Carolus Utenhouus gave to me.

$\mathrm{He}$, the support, honor, and pious care of my father, thought these poems should be sent by his mistress.

The eminent name or fame of the idle court is trivial, deceitful, and has nothing of piety.

Take care that you not be deceived. There is no piety in the court, while the vain crowd sees something great in it.

The one who comes from the court, and whom the court often receives, rejoices at being pointed out with a finger and loves to be revered.

The king nourishes him whom the fierce steed, champing at the bit, carries; the people trust him and consider him the equal of a demigod.

Now, to be called courtly is nearly divine, and the court is for many what the lofty halls are for Jupiter.

When nothing is more faithless or anything emptier than the court, then it is my care to ask what the court expresses.

What now means "court" in Latin meant "stable" for the Greeks, that is, a covered shelter and a pen for pigs and sheep. ${ }^{58}$

Those the ancient Romans once called aulae.

Now the court of kings is called a royal palace,

which is nothing but the ugly dregs of evil humans, among whom depravity lies concealed by embellishment!

It is better for many to live in a fold than to live in the court.

The fold holds the just, but the impious court holds the bad.

The master of goats and sheep in the fold is unrefined, and the flock of the fleecy and the bristly is innocent.

58 Lines 19-21 are an explanation of the word aula (cf. Greek $\alpha \dot{\lambda} \lambda \dot{\text { ) }}$ which could also mean a court for cattle (Lewis \& Short I). The Greek definition (a steading for cattle) has now come to mean a royal court in contemporary Latin usage.

Humanistica Lovaniensia 70.2 (2021), 209-227 
Purpureos reges, dira feritate tyrannos,

Penelopes sponsos, aula superba tenet.

Affecti pecoris placide contagia sanat caula, dabit dominis vellera densa suis.

Aula bonos laedit, miseros compilat et inde affluit innumeris perdita deliciis.

Ut ferus innocuo lupus insidiatur ovili, ${ }^{59}$ impia sic passim coetibus aula piis.

Quique gravi duram terram proscindit aratro, ${ }^{60}$ is tenui in caulis lance quietus agit; otia qui reprobis sectantur mollia in aulis, pauperis immenso parta labore vorant.

Morum simplicitas, vitae inculpanda ${ }^{61}$ probatae, et veri et iusti suspiciendus amor, iustitia et pietas, patientia sedulitasque, mansuetudo animi, cum probitate fides, caulas atque casas humiles moderantur et ornant, quas penes est purae relligionis amor.

Aula sodalitium perversum habet atque superbum, quae nolente pio rege volente mala est.

Fraudes atque dolos probat et mendacia laudat, adsentatorum est aulica turba cohors.

Prodiga, mollis, iners, vinosa, immitis et excors turpibus aes fundit rebus, avara bonis.

Consilia in dubiis ${ }^{62}$ laudat crudelia rebus et paci praefert impia bella sacrae.

Adde quod et regum pervertit corda bonorum: cras, qui nunc placidus, forte tyrannus erit!

I nunc, docta Camilla, i nunc et pronuba fias sponsae, quae socias format amatque malas. ite duces, comites, satrapae, celsique tyranni, sunt quibus et fidei nomine sceptra sacrae,

59 Similar language about wolves can be found at Verg. Buc 5.60, Georg. 3.537, and Aen. 9.59

${ }^{60}$ A variation on Horace's ille grauem duro terram qui uertit aratro (Sat. 1.1.28)

61 An uncommon word that is perhaps better read as inculcanda. I have retained the manuscript spelling because of the attestation of inculpandus as an adjective with the meaning "blameless".

62 Reading in dubiis instead of indubiis. 
The haughty court has kings clothed in purple, tyrants of terrible cruelty, and the suitors of Penelope.

The fold calmly cures the ailments of the afflicted flock. It will give thick fleeces to its masters.

The court injures the good, steals from the wretched, and then, corrupted, overflows with countless luxuries.

As the fierce wolf lies in wait for the innocent sheep, so the impious court lies in wait for the pious crowds.

He who breaks up the rough land with a hard plow leads a quiet life in his fold with a small plate.

Those who in base courts pursue easy leisure, squander things borne from the immense labor of the poor.

The honesty of morals - blameless in a good lifeand the love of what is true and just should be admired:

Justice, piety, patience, earnestness, gentleness of the soul, trustworthiness with honesty-

these guide and adorn folds and humble homes, where there is the love of pure religion.

The court, having misguided and arrogant company, is bad, whether or not the pious king wants it.

The courtly crowd commends guile and deceit and lauds falsehoods; it is a throng of flatterers.

Lavish, soft, indolent, filled with wine, harsh, and senseless, it casts money for vile things, while it is greedy in the case of

It praises cruel counsels in uncertain matters, good things. and prefers impious wars to holy peace.

Add that it corrupts even the hearts of good kings.

Tomorrow, he who is now peaceful, will by chance become a tyrant.

Go now, learned Camilla, go now and may you be the attendant of a bride-to-be, who makes and loves her bad companions.

Go, leaders, courtiers, governors, and proud tyrants, you who have royal staffs under the name of holy faith, 
quas ecclesia habet rebus succurrite lapsis, cum scateat vobis moribus aula malis.

Aula suam recte scabiem prius impia purget, quam sacri coetus tollere damna paret.

Emendata pie morum medicina bonorum collapsa instauret regia tecta prius,

quam studeat verbi divini oracla malorum inferre in Lernam, se exoneretque prius.

Impuros inter dominos scelerumque magistros, pars aut sors Christo nec locus esse potest.

In caulis Patriarchae ipsi vixisse leguntur, struxisse et caulas et stabulasse boves; in caula est humili Christus, non natus in aula: caula dat innocuis rustica perfugium.

Baptista ad caulas vixit sanctissimus inter foeminea genitos stirpe; quid, aula, tumes?

Foedius est nil te, nil te est indignius usquam, sanctorum innocuo dira cruore mades.

Irrisus, caesus, crudeli Christus in aula est, quique decus coeli est, dedecus, aula, tuum est,

quem iurans Petrus novisse negabat in aula: perversi sensit damna sodalitii.

Recte igitur nostris suasum maioribus olim, exeat aula omnis qui volet esse pius. 
assist with the falling matters which the church has, since court for you abounds in evil customs.

May the impious court first rightly cleanse its own disease, before it prepares to remove the defects of the holy assembly.

Let the medicine of good morals, piously faultless, restore the royal roofs which had collapsed.

Let the court first unburden itself of its sin before it desires to bring oracles of the divine word to an accumulation of ills. ${ }^{63}$

Among unclean masters and teachers of wickedness, there can be no part or share of Christ, nor a place.

The Patriarchs themselves are said to have lived in the folds, to have built folds, and to have stabled cattle.

Christ was born in a humble fold, not in a court. The rustic fold gives refuge to the innocent.

The most holy Baptist lived near the folds among

those born from a female line - why do you swell with pride, court?

Nothing is uglier than you, nothing anywhere is more shameful.

You, harsh, are drenched in the innocent blood of the holy.

Christ was mocked and killed in a cruel court.

And he who is the honor of heaven, court is your shame.

Peter, swearing falsely, refused to acknowledge him in a court. ${ }^{64}$

He experienced the harm of bad company.

Thus our ancestors once had this just conviction:

Whoever desires to be pious, let him leave the court.

University of Michigan, Ann Arbor kkarmen@umich.edu

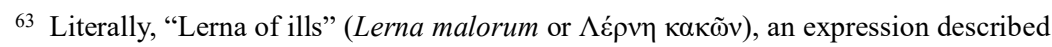
by Erasmus as de malis item plurimis simul in unum congestis et accumulatis (Adagia 1.3.27). Argive Lerna was an ancient cult site where the mysteries of Demeter Prosymnia and Dionysus Bugenes ("cow-born") were celebrated in the annual Lernaea festival. In these cult celebrations, there would be an epiphany of the tauromorphic Dionysus, leading his mother Semele from the underworld (Brill's New Pauly, s.v. "Lernaea" [Baudy]). Catherine de Médicis was known to be interested in astrology and the occult, even inviting the astrologer Nostradamus (1503-1566) to her court.;

64 This refers to Peter's denial of Jesus: "he refused to acknowledge him (i.e., Christ) in a court (i.e., of the high priest)." The denials of Peter are described in Luc. 22:54-57, Marc. 14: 69-70, Matth. 26: 73-75, Luc. 22: 59-62, and Ioh. 18: 13-27.

Humanistica Lovaniensia 70.2 (2021), 209-227 